The oldest representative of the modern snipe fly genus Symphoromyia (Diptera: Rhagionidae)

\title{
ANDRE NEL ${ }^{1}$, ZIANN PERREAU ${ }^{2}$ \& GAELLE DOITTEAU ${ }^{3}$
}

${ }^{1}$ Institut de Systématique, Évolution, Biodiversité, ISYEB - UMR 7205 - CNRS, MNHN, UPMC, EPHE, Muséum national d'Histoire naturelle, Sorbonne Universités, 57 rue Cuvier, CP 50, Entomologie, F-75005, Paris, France.E-mail: anel@mnhn.fr

${ }^{2} 27$ Quai d'Anjou, F-75004 Paris, France.E-mail: perreauziann@yahoo.fr

${ }^{3}$ E-Recolnat, MNHN, Bâtiment 140, Îlot Buffon-Poliveau, 43 rue Buffon, F-75005 Paris, France.E-mail: gaelle.doitteau@mnhn.fr

\begin{abstract}
We describe and illustrate from the earliest Eocene amber of France the oldest representative of the rhagionid modern genus Symphoromyia, under the name of S. eocenica sp. nov. Its mouthpart structure shows that it was hematophagous as is the modern representatives of the genus, demonstrating a remarkable morphological stability for 53 Myr.
\end{abstract}

Key words: Diptera, Rhagionidae, Symphoromyia, Eocene, Oise amber.

\section{Introduction}

As a very ancient brachyceran group, the rhagionid flies may provide insights into the early evolution of the Tabanomorpha. Kerr (2010) provided an extensive phylogeny and classification of the snipe flies. Fossils are rather frequent, especially in the Mesozoic (see fossil record in Zhang 2013; Angelini et al., 2016). The majority of the Cenozoic species were 
described from the Eocene Baltic amber (Evenhuis 1994). Most of fossil snipe flies are compressions with crucial structures hardly visible. With seven described species, the modern blood-sucking genus Symphoromyia Frauenfeld, 1867 seems to be among those with the greatest number of fossil representatives (after Rhagio Fabricius, 1775), all from the Middle Eocene to Early Oligocene (Evenhuis, 1994, 2014). Here we describe a new earliest Eocene fossil that corresponds to the oldest representative of this genus.

\section{Material and methods}

The Oise amber deposit is located near Creil at the place known as "Le Quesnoy” (Oise, northern France). The lignite layers containing the amber belong to the Lower Eocene of the Paris basin ( $\sim 53 \mathrm{Ma})$. This age corresponds to Paleocene-Eocene Thermal Maximum (PETM), one of the most important periods of global warming. Data from the evaluation of flora and fauna in Oise amber suggest a semideciduous forest under a hot climate with a wet and a dry season. Representatives of the Combretaceae or Caesalpiniaceae are considered as amber producing trees in this region. Up to date, 20,000 amber inclusions have been collected from this site, including hexapods, mites, spiders, and two pseudoscorpions. Plant remains (leaves, seeds, flowers, pollen), fungi and microorganisms are also very abundant (for review see Nel et al., 1999; Brasero et al. 2009).

The piece of amber with the type specimen of Symphoromyia eocenica sp. nov. was polished and included into Canada balsam between two glasses. The fossil was examined and measured using an incident light (Olympus SZX9), and a Leitz Wetzlar binocular microscope and combined using Adobe Photoshop software.

\section{Systematic Palaeontology}

Order Diptera Linnaeus, 1758. 
Superfamily Rhagionoidea Latreille, 1802.

Family Rhagionidae Latreille, 1802

Genus Symphoromyia Frauenfeld, 1867

Symphoromyia eocenica sp. nov.

(Figs. 1-3)

Etymology. Named after the Eocene period.

Material. Holotype MNHN.F.A57537 (PA 2496, sex unknown), stored in the laboratory of palaeontology, MNHN, Paris.

Type locality. Farm Le Quesnoy, 49¹9'31" N, 240'22" E, Chevrière, Region of Creil, Oise Department (northern France).

Type horizon. Lowermost Eocene amber, Sparnacian (53 Ma), level MP7 of the mammal fauna of Dormaal (Brasero et al. 2009).

Diagnosis. Clypeus bulbous; postspiracular sclerite smooth and flat; hind tibial spur one; R2+3 well separated from R1 at apices; M3 present, reaching wing margin; laterotergite setose; macrochaetae of hind tibia absent; palpus two-segmented; scale-like thoracic setae absent; first antennal flagellomere kidney-shaped, convex below arista, arista subterminal and anterodorsal; mandibles present; wing ca. $4.2 \mathrm{~mm}$ long; body ca. $5.1 \mathrm{~mm}$ long.

Description. Body ca. $5.1 \mathrm{~mm}$ long. Head $0.71 \mathrm{~mm}$ long, ca. $1.0 \mathrm{~mm}$ high. Clypeus bulbous. Face bare between eyes. Scape $0.07 \mathrm{~mm}$ long, $0.08 \mathrm{~mm}$ high, clearly larger than pedicel. First flagellomere of antenna kidney-shaped, convex below arista, laterally compressed, enlarged, bearing a long subterminal anterodorsal arista. Eyes large, without visible setae; distinctly separated. Labella ca. $0.79 \mathrm{~mm}$ long, slightly shorter than height of head. Palpus twosegmented, distal segment setose, $0.24 \mathrm{~mm}$ long, longer than proximal segment, ca. $0.2 \mathrm{~mm}$ long. Lacinia longer than palpus, with serrated tip. Mandibles long and acute.

Thorax $1.6 \mathrm{~mm}$ long. Dorsocentral bristles of mesonotum absent; all dorsal setae of equal 
length. Anepisternum setulose throughout posterior half. Laterotergite setose. Postspiracular sclerite smooth and flat. Prescutellum present. Subscutellum inconspicuous. Wing apparently hyaline, without markings or membrane lightly to moderately infuscate, brownish. Lower calypter reduced. Upper calypter well developed, with broad curvature, lobe-like. Wing ca. $4.2 \mathrm{~mm}$ long, $1.6 \mathrm{~mm}$ wide. Apex of costa not preserved. Humeral crossvein well developed. Crossvein sc-r weakly developed, positioned distal to $\mathrm{h}$ a little less than length of $\mathrm{h} . \mathrm{R}_{1}$ and $\mathrm{R}_{2+3}$ separated at wing margin. Dorsal side of $\mathrm{R}_{1}$ setulose, ventral side bare. All other wing veins without setulae. Apical third of $\mathrm{R}_{2+3}$ ultimately bends anteriorly slightly, toward leading edge of wing margin. Length of $\mathrm{R}_{2+3}$ probably shorter than $\mathrm{R} 5$. Base of $\mathrm{R}_{4+5}$ fork proximal distal end of cell dm. $R_{4}$ nearly straight apically. $R_{5}$ probably posterior to wing tip, clearly longer than $\mathrm{R}_{4+5}$. Crossvein $\mathrm{r}-\mathrm{m}$ at proximal one-third of discal cell. $\mathrm{M}_{3}$ present. Crossvein mcu present. Origin of $\mathrm{CuA}_{1}$ at cell bm near discal cell. $\mathrm{M}_{3}$ cell at margin convergent. $\mathrm{Cu}_{2}$ length ca. 2/3 the length of posterior vein of cell bm. Alula with broad, evenly rounded curvature. Anal lobe well developed. Cell cup open. Halter knob approximately 3/5 length of stem. Tibial spur formula 0:2:1. Hind tibial macrochaetae absent.

Abdomen ca. $2.4 \mathrm{~mm}$ long, $1.2 \mathrm{~mm}$ high. Abdominal segments evenly tapered. Segmentation not clearly visible, last 3 abdominal segments telescoped; genitalia not visible.

\section{Discussion}

If we follow the key to fly families of McAlpine (1981), this fossil would fall in the Rhagionidae for the following characters: empodia pulvilliform; head more than half as wide as thorax; eyes not holoptic (female); subscutellum weakly developed; wing with anal lobe well-developed; clypeus exposed and convex; distal flagellomeres forming an arista. The reniform first flagellomere would suggest possible affinities with the Athericidae (but also present in some Rhagionidae), but Athericidae are excluded for the absence of one main 
synapomorphy, viz. wing veins $\mathrm{R}_{1}$ and $\mathrm{R}_{2+3}$ meeting together at the wing margin (Kerr 2010) (note that $\mathrm{R}_{1}$ and $\mathrm{R}_{2+3}$ are also strongly approximate in some Rhagionidae, e.g., Chrysopilus balbii Santos \& Amorim, 2007). If we follow the key to adult genera of Rhagionoidea of Kerr (2010), this fossil falls in the genus Symphoromyia for the following characters: Clypeus bulbous; postspiracular sclerite smooth and flat; hind tibial spur one; M3 present, reaching wing margin; laterotergite setose; macrochaetae of hind tibia absent; palpus two-segmented; scale-like thoracic setae absent; first antennal flagellomere kidney-shaped, with dorsoapical arista; and mandibles present. The enlarged scape and the aristate and kidney-shaped in profile flagellomere are autapomorphic characters of this genus, after Kerr (2010).

Many modern species within the genus Symphoromyia are separated on the basis of body and leg coloration (Turner, 1974), which are not visible in this fossil. Also the lack of information on the genitalia structures forbid us to compare this fossil with the different modern species. Nevertheless as it is relatively old, it certainly belongs to an extinct new species.

Cockerell (1911) described Symphoromyia subtrita from the Early Oligocene of Florissant (Colorado) and Théobald (1937) described Symphoromyia marginata from the Early Oligocene of Kleinkembs (Germany, Rhine Valley), both on the basis of compression fossils. These fossils show clearly less characters than the present one for an attribution to the genus Symphoromyia. They should be revised to verify their attribution. Our fossil has a wing shorter than those of S. marginata and S. subtrita, allowing to consider that it belongs to a different species.

Meunier (1910) described Atherix evecta, A. examinata, and A. exigua from the Middle Eocene Baltic amber, later transferred into the genus Symphoromyia (Meunier 1916; Hennig 1967; Stuckenberg 1974). All these species have wings smaller than S. eocenica (2.5 to $3.5 \mathrm{~mm}$ long instead of $4.2 \mathrm{~mm}$ long). Paramonov (1936) described S. succini and S. tertiarica from the Baltic amber. The first flagellomere of $S$. tertiarica has a shape different 
from that of S. eocenica, i.e. with part below arista straight. Both S. succini and S. tertiarica have wings smaller than S. eocenica (3.0-3.5 mm long).

All fossils currently attributed to Symphoromyia should be revised to verify if they show all the characters diagnostic of this genus, especially the antennal structures.

Modern Symphoromyia species are Holarctic. Female take blood meals from vertebrate hosts (Kerr 2010). The presence of acute mandibles and laciniae in S. eocenica indicates that it was probably also a hematophagous insect.

\section{Acknowledgements}

We sincerely thank Charles Morphy D. Santos and Neals Evenhuis for their very useful comments on the first version of the paper. We also thank the Lafarge-Granulat company for help with the fossil sampling and the Langlois-Meurinne family for the authorization of working on their property.

\section{References}

Angelini, P.-A., Dany Azar, A. \& Nel, A. (2016) A new genus and species of snipe fly (Diptera: Rhagionidae) in Lebanese Cretaceous amber. Cretaceous Research, 58, 10-16.

Brasero, N., Nel, A. \& Michez, D. (2009) Insects from the Early Eocene amber of Oise (France): diversity and palaeontological significance. Denisia, 26, 41-52.

Cockerell, T.D.A. (1911) Fossil insects from Florissant, Colorado. Bulletin of the American Museum of Natural History, 30, 71-82.

Evenhuis, N.L. (1994) Catalogue of the fossil flies of the world (Insecta: Diptera). Backhuys Publishers, Leiden: 600 pp.

Evenhuis, N.L. (2014) Catalog of the fossil flies of the world (Insecta: Diptera) (Version 2.0). Internet site: http://hbs.bishopmuseum.org/fossilcat/ (accessed 03 October 2016). 
Hennig, W. (1967) Die sogenannten “niederen Brachycera” im Baltischen Bernstein (Diptera: Xylophagidae, Xylomyidae, Rhagionidae, Tabanidae). Stuttgarter Beiträge zur Naturkunde, $174,1-51$.

Kerr, P.H. (2010) Phylogeny and classification of Rhagionidae, with implications for Tabanomorpha (Diptera: Brachycera). Zootaxa, 2592, 1-133.

McAlpine, J. F. (1981) Key to families, adult. In: J. F. McAlpine, B. V. Peterson, G. E. Shewell, H. J. Teskey, J. R. Vockeroth, D. M. Wood (coordinators), Agricultural Canada Monograph: Vol. 27. Manual of Nearctic Diptera, 1, research Branch, pp. 89-124.

Meunier, F. (1910) Monographie der Leptiden und der Phoriden des Bernsteins. Jahrbuch der Königlische Preussischen Geologische Landesanstalt, 28, 64-90.

Meunier, F. (1916) Sur quelques Diptères (Bombylidae, Leptidae, Dolichopodidae, Conopidae, Chironomidae) de l'ambre de la Baltique. Tijdschrift voor Entomologie, 59, 274286.

Paramonov, S.J. (1936) [On the entomofauna of ambers.] Trudy Instituta Zoologii Akademiia nauk SSSR Kiev, 18, 53-64. (in Russian).

Nel, A., de Ploëg, G., Dejax, J., Dutheil, D., de Franceschi, D., Gheerbrant, E., Godinot, M., Hervet, S., Menier, J.-J., Augé, M., Bignot, G., Cavagnetto, C., Duffaud, S., Gaudant, J., Hua, S., Jossang, A., de Lapparent de Broin, F., Pozzi, J.-P., Paicheler, J.-C., Bouchet, F. \& Rage, J.-C. (1999) Un gisement sparnacien exceptionnel à plantes, arthropodes et vertébrés (Éocène basal, MP7): Le Quesnoy (Oise, France). Comptes-Rendus de l'Académie des Sciences, Paris, (IIa), 329, 65-72.

Santos, C.M.D. \& Amorim, D. de Souza (2007) Chrysopilus (Diptera: Rhagionidae) from Brazil: redescription of Chrysopilus fascipennis Bromley and description of eleven new species. Zootaxa, 1510, 1-33.

Stuckenberg, B.R. (1974) A new genus and two new species of Athericidae (Diptera) in Baltic 
amber. Annals of the Natal Museum, 22, 275-288.

Théobald, N. (1937) Les insectes fossiles des terrains oligocènes de France. Bulletin Mensuel (Mémoires) de la Société des Sciences de Nancy, 1, 1-473.

Turner, W.J. (1974) A revision of the genus Symphoromyia Frauenfeld (Diptera: Rhagionidae). I. Introduction, subgenera and species-groups, review of biology. Canadian Entomologist, 106, 851-868.

Zhang, Junfeng (2013) Snipe flies (Diptera: Rhagionidae) from the Daohugou Formation (Jurassic), Inner Mongolia, and the systematic position of related records in China. Palaeontology, 56, 217-228.

List of figures

FIGURE 1. Symphoromyia eocenica sp. nov., holotype MNHN.F.A57537. Habitus. A, left side; B, right side.

FIGURE 2. Symphoromyia eocenica sp. nov., holotype MNHN.F.A57537. A, head, white arrow first flagellomere; black arrows palpomeres; B, thorax, abdomen, and wing. FIGURE 3. Symphoromyia eocenica sp. nov., holotype MNHN.F.A57537. Wing. FIGURE 4. Symphoromyia eocenica sp. nov., holotype MNHN.F.A57537. A, lateral view of thorax and abdomen; B, legs. 


\section{Sc $\quad R 1$}

\section{$\mathrm{R} 2+3$}

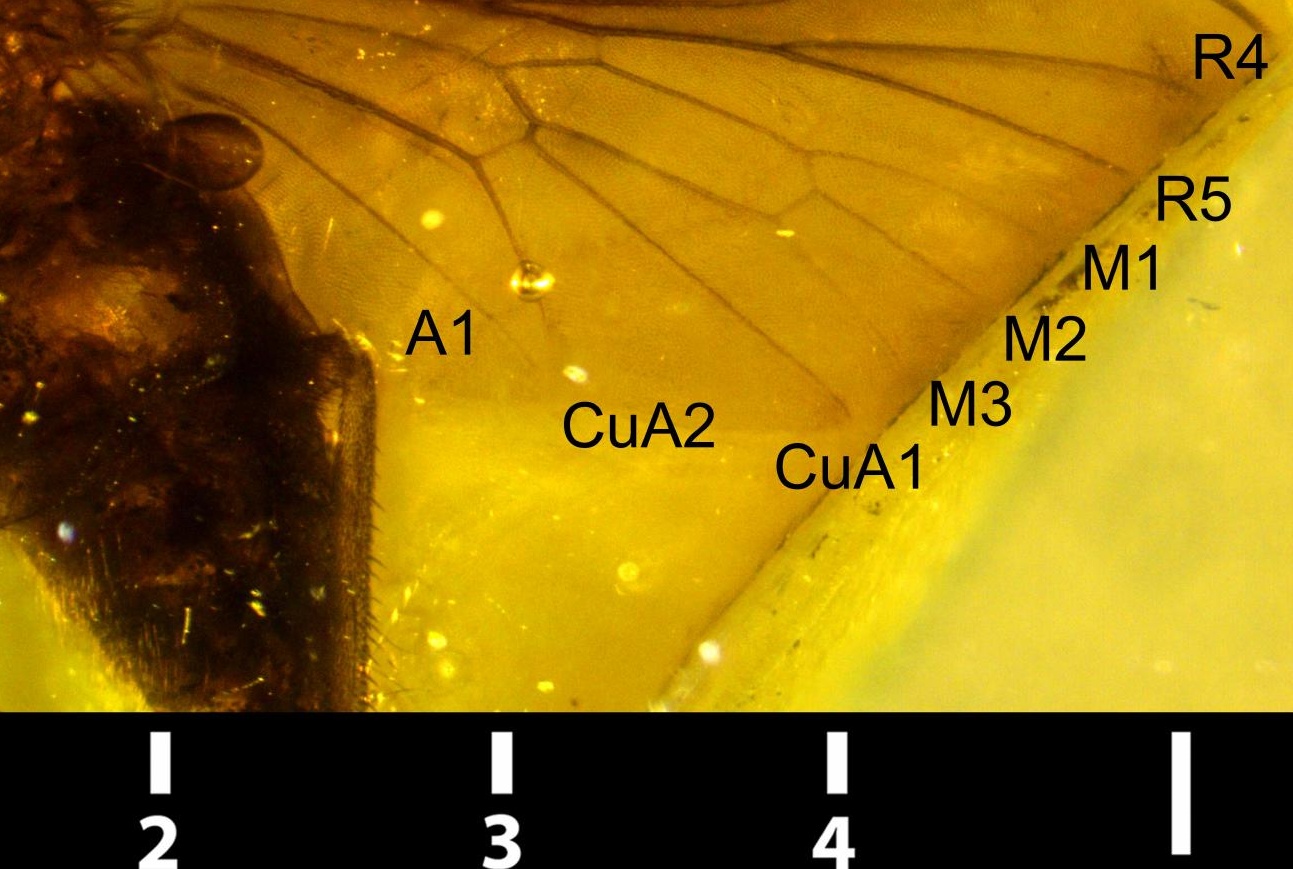



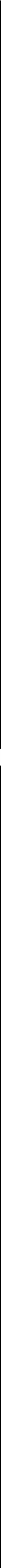